\title{
Effects of a Furrow-Bed Seeding System on Stand Establishment, Soil Bacterial Diversity, and the Yield and Quality of Alfalfa Grown in Saline Soils
}

\author{
Juanjuan Sun \\ Institute of Grassland Research of Chinese Academy of Agricultural Sciences \\ Jinmei Zhao \\ Institute of Grassland Research of Chinese Academy of Agricultural Sciences \\ Linqing Yu \\ Institute of Grassland Research of Chinese Academy of Agricultural Sciences \\ Tengwei Z \\ Institute of Grassland Research of Chinese Academy of Agricultural Sciences \\ Yuntao Wang \\ Institute of Grassland Research of Chinese Academy of Agricultural Sciences \\ Ke Jin ( $\nabla$ jinke@caas.cn) \\ Institute of Grassland Research of Chinese Academy of Agricultural Sciences
}

\section{Research Article}

Keywords: Medicago sativa L, Furrow-bed seeding, soil bacterial diversity, Na+ concentration, yield, soil moisture

Posted Date: December 6th, 2021

DOI: https://doi.org/10.21203/rs.3.rs-1113836/v1

License: (c) (1) This work is licensed under a Creative Commons Attribution 4.0 International License. Read Full License 


\section{Abstract}

Purpose: To compare the performance of alfalfa crops and soil properties between a furrow-bed seeding system (FU) and a flat-bed seeding system (FL) in saline soil.

Methods: Alfalfa seeds were sown in early fall, 2019, in saline sandy loam soil using FU and FL systems. The soil temperature, moisture, root-zone salinity, bacterial diversity, seedling emergence number in 2019 and soil nutrient contents, alfalfa production characteristics in 2020 were determined for plants in FU and FL treatments.

Results: Compared with FL, FU resulted in increased soil moisture content and seedling emergence, and reduced relative abundance of Actinobacteria and Choroflexi in soil at the seedling stage, but it did not affect root-zone salinity. In April 2020, the soil salinity was lower, and the soil available phosphorus, potassium, nitrogen, and soil organic matter contents were higher, in FU than in FL. Compared with FL, FU resulted in increased yield (by $37.5 \%$ ), protein content (by 3.6\%), and potassium concentration (by 33.2\%), and decreased ash content (by 7.7\%) and sodium concentration (by $19.0 \%$ ) in alfalfa plants. The increased yield was positively correlated with seedling emergence, soil available potassium, total nitrogen, and organic matter contents, and shoot potassium content; and negatively correlated with shoot sodium content. The relative abundance of Actinobacteria was negatively correlated with alfalfa ash, calcium, and sodium concentrations, and positively correlated with shoot potassium content. Overall, FU increased alfalfa quality and alleviated salt stress.

Conclusions: Furrow-bed seeding in early fall can enhance the yield and quality of alfalfa cultivated in saline soils.

\section{Introduction}

Soil salinization is a growing problem for agriculture worldwide (Deinlein et al. 2014), especially in arid and semiarid regions. Gansu, Inner Mongolia, Xinjiang, Ningxia, Heilongjiang, and Hebei provinces are the major alfalfa-growing areas in China. Although these six provinces produce $89.9 \%$ of Chinese high-quality alfalfa, they have almost two-thirds (65.7\%) of the area of saline soil in China. Soil salinity, limited rainfall in spring, high evapotranspiration rates, and poor water management are among the main challenges for agricultural production in this area.

Alfalfa is the most important forage crop in China. Although it is classified as moderately salt tolerant (Noble et al. 1984), it has been well documented that salt stress inhibits alfalfa shoot growth and increases the shoot sodium $\left(\mathrm{Na}^{+}\right)$concentration (Sun et al. 2016). Salinity negatively affects alfalfa growth when the electrical conductivity (EC) of soil is above $2-3.5 \mathrm{dSm}^{-1}$, and its effects also vary depending on the stage plant growth and development. Alfalfa is very sensitive to salt stress during germination (Allen et al. 1985), at the seedling stage (Ashraf et al. 1987; Esechie et al. 2002), and at the pre-flowering stage (Noble et al. 1984). The accumulated salt in the soil inhibits seed germination, seedling emergence, and plant growth and development through osmotic effects, by causing nutritional imbalances, or by toxicity of salt ions $\left(\mathrm{Na}^{+}\right.$and $\left.\mathrm{Cl}^{-}\right)$. This leads to sparse germination, stunted plants, and/or reduced crop yield and quality (Latrach et al. 2014). Low soil moisture also negatively affects alfalfa seedling emergence and crop establishment. In fact, soil moisture is one of the most important factors affecting crop productivity (Liu et al. 2010).

Planting patterns affect water and salt transport by controlling evaporation and distributing rainfall, and they are inexpensive and do not pollute the soil. Thus, the use of suitable planting patterns is an environmentally friendly way to moderate soil salinity (Devkota et al. 2015). In arid and semi-arid areas, the soils are highly saline with a low moisture content. Consequently, crop productivity in such areas is low, and it cannot meet local food demands. Controlling salinity in the root-zone so that it is below harmful levels (reducing root-zone salinity) is one beneficial strategy to improve crop emergence and stand establishment in saline fields (Meiri and Plaut 1985). Previous studies have shown that a furrow-bed seeding system (FU) can efficiently collect rainfall and leach salt from the root zone (Dong et al. 2009; Sun et al. 2017a), so it may be a promising planting pattern for agricultural reclamation in saline-alkaline areas around the world. Dong et al. (2010) found that over-irrigation before planting in an FU system consisting of alternate parallel ridges and furrows on flat land after leaching improved stand establishment and yield (Dong et al. 2010). This was because salts moved upward by capillary action under an evaporation gradient, and accumulated on the soil surface after planting (Dong et al. 2009). The FU system results in the unequal distribution of salts in the surface soil layers (Meiri and Plaut 1985). Unequal salt distribution under controlled conditions has been shown to affect the physiological characteristics of alfalfa and improve its growth (Sun et al. 2016; Sun et al. 2017b; Xiong et al. 2020). However, it is unknown whether the use of an FU system can improve the growth and yield of alfalfa and the properties of soil in saline soil environments.

The plastic-covered ridge and furrow rainwater harvesting system (PRRFHS) is a well-known soil -water conservation practice used in crop production (Liu et al. 2014; Cuello et al. 2015), and it is one of the most efficient technical applications for maximizing rainfall use. The PRRFHS can improve soil moisture availability in the crop root zone by collecting water from light rain, and this can significantly increase crop yield and water-use efficiency (Liu et al. 2014). It also reduces evaporation and promotes rainfall infiltration and has been widely used in maize and cotton production (Li et al. 2000). However, mulching with plastic also has some negative effects, including plastic waste, greenhouse gas emissions associated with the production of the film (Cuello et al. 2015), and increased planting costs. To date, there have been no studies on the effects of growing alfalfa in a ridge-furrow crop system with no mulch and with a narrow planting belt under saline conditions.

In the soil microbial community, bacteria are one of the richest and most diverse microbial groups, and they play important roles in many soil processes. They participate in soil nutrient cycling, the decomposition of organic matter and waste, the degradation of pesticides and contaminants, and soil aggregation and humus formation. In addition, they affect the soil structure and the growth and health of plants (Jurburg et al. 2018). Soil microbial populations and community composition are affected by a range of edaphic factors, such as soil physicochemical properties (Wakelin et al. 2007) and soil management practices (Chen et al. 2014). Nutrient substrates (Ling et al. 2017), soil pH (Bainard et al. 2016), salinity (Guo et al. 2018), moisture (Battin et al. 2003; Nguyen et al. 2018; Yang et al. 2019; Chi et al. 2021), and plant community cover (Bainard et al. 2016) are the main ecological drivers of soil bacterial abundance, diversity, and community composition. In particular, soil carbon (C) and nitrogen (N) contents strongly affect soil bacteria, because they decompose soil 
organic $\mathrm{C}$ and $\mathrm{N}$ to obtain energy (Yang et al. 2018). For example, Chloroflexi, Nitrospirae, and Planctomycetes tend to be abundant in nutrient-poor soil where they show slow growth rates and use recalcitrant $\mathrm{C}$ substrates (Nie et al. 2018). In contrast, Proteobacteria and Bacteroidetes favor nutrient-rich conditions and utilize labile $\mathrm{C}$ materials (Philippot et al. 2013). A previous study found that soil salinity negatively affects the abundance of most bacterial groups, but has little effect on bacterial diversity (Gao et al. 2015). Consequently, determining the effects of different planting systems on the soil bacterial community can shed light on how such planting systems affect plant growth.

Soil ridging with plastic film has been shown to improve rainwater utilization and improve alfalfa yield in semiarid areas where alfalfa production is largely rainfed (Gu et al., 2018, Li et al., 2007), However the width of bare soil between planting belts is increased from 30 to $60 \mathrm{~cm}$ (Li et al., 2007 ), the wider planting belts cause higher evaporation. Numerous field studies have explored the effects of the FU system on soil properties, especially soil moisture content, and plant yield. However, few have explored the effects of the narrow plant row FU system on alfalfa grown in saline soils. In addition, the effects of FU on soil bacterial diversity at the seedling stage and the relationships among soil microbes, soil properties, crop yield, and crop quality need further study. Therefore, the objectives of this study were as follows: (1) to evaluate the effects of the FU seeding system with a narrow plant belt on soil properties (especially salinity), soil bacterial diversity at the seedling stage, and alfalfa yield and quality in the second growth year; and (2) investigate the relationships among soil water content, soil microbes, soil nutrient contents, soil salinity, and the growth and physiology of alfalfa plants. Therefore, a 2-year field experiment was conducted to explore these topics in detail.

\section{Materials And Methods Experimental Site}

A field experiment was conducted in an area with saline sandy loam soil in the Hohhot district $\left(111^{\circ} 45^{\prime} \mathrm{E}, 40^{\circ} 36^{\prime} \mathrm{N}\right)$ on the Tumochuan plain, China, during two consecutive alfalfa growing seasons: 2019 and 2020 . The site has a typical continental climate with mean annual air temperature of $7.6^{\circ} \mathrm{C}$ and mean annual maximum and minimum air temperatures of $23.3^{\circ} \mathrm{C}$ (July) and $-11.0^{\circ} \mathrm{C}$ (January), respectively. The mean annual precipitation is $392.6 \mathrm{~mm}$ (average values for 1981-2010), and around $74.8 \%$ of the precipitation occurs between July and September. The potential annual evaporation is about $1757.1 \mathrm{~mm}$. Mean annual sunshine exceeds $2829.8 \mathrm{~h}$, and the frost-free period is about $137 \mathrm{~d}$ (range, $99 \mathrm{~d}$ to $183 \mathrm{~d}$ ). The distribution of precipitation in 2019 and 2020 is shown in Fig. 1.

The properties of the background surface soil (0-15 cm) were as follows: $15.9 \mathrm{~g} \mathrm{~kg}^{-1}$ soil organic matter (SOM), $930 \mathrm{mg} \mathrm{kg}^{-1}$ total N, $14 \mathrm{mg} \mathrm{kg}^{-1}$ available phosphorus (P), and $225 \mathrm{mg} \mathrm{kg}^{-1}$ available potassium (K), with an ECe (electrical conductivity of a saturated soil extract) of $15.8 \mathrm{dSm}{ }^{-1}$ in spring and with an ECp (electrical conductivity of pore water) of $1.1 \mathrm{dSm}^{-1}$ in early fall. Alfalfa seeds were sown in early August (fall) in 2019.

\section{Experimental Design and Field Management}

The cold-tolerant alfalfa cultivar Medicago sativa L. cv. "Zhongcao NO.3", bred by Linqing Yu, Chinese Academy of Agricultural Sciences, was selected for this study, as it is widely cultivated on the Inner Mongolia plateau in China. The experiment comprised two cultivation systems: furrow-bed seeding (FU) (cultivation with ridges and furrows) and flat-bed seeding (FL) (conventional flat cultivation without ridges). The experiment had a completely randomized block design with four replicates. Each plot was 20.0-m long and 3.2-m wide. Alfalfa seeds were planted on 8 August 2019 using the drill planting method with a hand-pushed vegetable planter. For the FU treatment, the width of the ridges and the furrows was $35 \mathrm{~cm}$ and $5 \mathrm{~cm}$, respectively, and the ridge height was 15 $\mathrm{cm}$. The furrows were leveled as planting belts (Fig. 2). The ridge and furrow were made using a tiny furrow machine and the ridges were compacted using a roller. Alfalfa seeds were drill-sown in the furrows in the FU system and then covered with $1 \mathrm{~cm}$ soil. All the planting rows in both FU and FL systems had a north-south orientation with 40 -cm spacing between adjacent rows. Weeds were controlled manually, with care taken not to destroy the ridge soil crust. Alfalfa plants were harvested manually in 2020 .

The alfalfa plants in the plots were not irrigated in 2019 because rainfall was sufficient that year, but were irrigated three times at key stages of growth in 2020. Other field management was conducted according to local agronomic practices.

\section{Data Collection}

Data were collected for rainfall, soil temperature, soil salinity, soil moisture content, seedling emergence number, soil bacterial diversity, soil properties, plant height, plant yield, shoot sodium $\left(\mathrm{Na}^{+}\right)$concentration, shoot $\mathrm{K}^{+}$concentration, shoot calcium $\left(\mathrm{Ca}^{2+}\right)$ concentration, and plant nutritional components.

Rainfall at the experimental site was measured using an automatic weather station (WSSTD1, Campbell Scientific, Loughborough, UK). The number of emerged seedlings (number of alfalfa seedlings at the cotyledon stage) was counted in five 100-cm-long seed-row sections and the average number per 100$\mathrm{cm}$-long seed-row in each plot at four, six, and nine days after seeding (DAS) was calculated. The soil moisture content, salinity, and temperature during the seedling stage at four, six, and nine DAS were determined by analyzing 10 surface $(0-10 \mathrm{~cm})$ soil samples with a HH2 Moisture Meter and a WET-2 sensor (Delta-T Devices Ltd. Cambridge, United Kingdom) (Kargas et al. 2011). For analyses of the soil bacterial community, five surface (0-15 cm) soil samples were collected from random positions along the crop row from each plot in both systems on 9 DAS. The soil samples from each plot were homogenized to form a composite sample and sieved through a $2 \mathrm{~mm}$ sieve to remove rocks and roots. A subsample was immediately stored at $-80^{\circ} \mathrm{C}$ until use in molecular analyses. 
For determination of the properties of the soil before the experiments started, ten soil cores were collected from random positions in the experimental field. For determination of soil salinity and the contents of SOM, total $\mathrm{N}$, available $\mathrm{P}$, and available $\mathrm{K}$ during the experiment, five soil cores were collected from random positions along the crop row to a depth of $15 \mathrm{~cm}$ from both the FU and FL treatment in the spring of 2020 when the alfalfa plants had just turned green. The soil samples from each plot were homogenized to form a composite sample. Subsamples were air-dried, ground, and passed through a 2-mm sieve, then used for analyses of soil salinity, SOM, available K, available P, and total N. Soil was mixed with water (1:5 soil to water ratio) to determine soil salinity. Soil chemical characteristics were tested following the method described by Bao(2018).

\section{Plant Characteristics}

Plant height was measured five times from Oct 17, 2019 to Jul 3, 2020. At each measurement time, 20 plants were selected from each plot and the height was measured and the average height of alfalfa were used. In 2020, the yield of the first cut of alfalfa was measured. Alfalfa plants were cut in a 1-m long part of the row, with three replicates per plot. The average yield from plants in $1 \mathrm{~m}$ was calculated, and used to estimate the yield per hectare. The harvested material was dried at $65^{\circ} \mathrm{C}$ for $48 \mathrm{~h}$ and then weighed to determine dry matter content. Then, the dried samples were ground to pass through 1-mm screen using a laboratory knife mill (FW100, Taisite Instruments, Tianjin, China) for later analysis. Neutral detergent fiber (NDF) (Van Soest et al. 1991) and acid detergent fiber (ADF) (Robertson and Van Soest 1981) were measured using an ANKOM fiber analyzer (ANKOM2000; Macedon, NY, USA). Crude ash (ash) content was determined by burning samples in a muffle furnace at $500^{\circ} \mathrm{C}$ for $5 \mathrm{~h}$ and then weighing the residue. Total nitrogen (total $\mathrm{N}$ ) content was determined by the Kjeldahl procedure (Krishnamoorthy et al., 1982); crude protein (CP) was determined by multiplying the total $\mathrm{N}$ by 6.25 . lons were extracted by shaking ground leaf samples in $0.5 \mathrm{M} \mathrm{HNO}_{3}$ in vials for $48 \mathrm{~h}$. Then, the diluted extracts were analyzed to determine their $\mathrm{Na}^{+}, \mathrm{K}^{+}$and $\mathrm{Ca}^{2+}$ contents using an $\mathrm{M} 410$ flame photometer (Sherwood, Cambridge, UK).

\section{DNA Extraction}

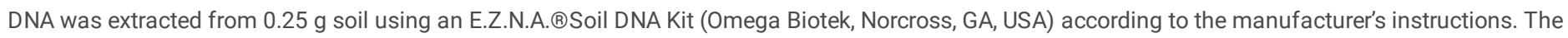
reagents in this kit were designed to isolate DNA from trace amounts of sample, and are effective for isolating DNA from most bacteria. Nucleic acid-free water was used as the blank. The total DNA was eluted in $50 \mu \mathrm{L}$ elution buffer and stored at $-80^{\circ} \mathrm{C}$ until PCR analyses by the LC-Bio Technology Co., Ltd (Hang Zhou, Zhejiang Province, China).

\section{PCR Amplification and 16S rDNA Sequencing}

The V3-V4 region of the prokaryotic (bacterial and archaeal) small-subunit 16S rDNA gene was amplified with slightly modified versions of the primers 338F (5'-ACTCCTACGGGAGGCAGCAG-3') and 806R (5'-GGACTACHVGGGTWTCTAAT-3'). The 5 ' ends of the primers were tagged with specific barcodes for each sample and universal sequencing primers.

Each PCR amplification reaction mixture contained 25 ng template DNA, $12.5 \mu \mathrm{L}$ PCR premix, $2.5 \mu \mathrm{L}$ each primer, and PCR-grade water to complete the volume to $25 \mu \mathrm{L}$. The thermal cycling conditions to amplify the prokaryotic $16 \mathrm{~S}$ fragments were as follows: initial denaturation at $98^{\circ} \mathrm{C}$ for $30 \mathrm{~s} ; 35 \mathrm{cycles}$ of denaturation at $98^{\circ} \mathrm{C}$ for $10 \mathrm{~s}$, annealing at $54^{\circ} \mathrm{C} / 52^{\circ} \mathrm{C}$ for $30 \mathrm{~s}$, and extension at $72^{\circ} \mathrm{C}$ for $45 \mathrm{~s}$; and then final extension at $72^{\circ} \mathrm{C}$ for 10 min. The PCR products were confirmed by $2 \%$ agarose gel electrophoresis. Throughout the DNA extraction process, ultrapure water, instead of a sample solution, was used to exclude the possibility of false-positive PCR results as a negative control. The PCR products were purified using AMPure XT beads (Beckman Coulter Genomics, Danvers, MA, USA) and quantified by Qubit (Invitrogen, Carlsbad, CA, USA). The amplicons were prepared for sequencing using a Library Quantification Kit for Illumina (Kapa Biosciences, Woburn, MA, USA), and the size and quantity of the amplicon library were assessed using an Agilent 2100 Bioanalyzer (Agilent, Palo Alto, CA, USA). The PhiX Control library (v3) (Illumina) was combined with the amplicon library (expected at 30\%). The libraries were sequenced with 300PE MiSeq runs. One library was sequenced with both protocols using standard Illumina sequencing primers, eliminating the need for a third (or fourth) index read.

\section{Data Analysis}

Samples were sequenced on the Illumina MiSeq platform according to the manufacturer's recommendations (LC-Bio). Paired-end reads were assigned to samples based on their unique barcode and truncated by cutting off the barcode and primer sequences. Paired-end reads were merged using FLASH. Quality filtering of the raw tags was performed under specific filtering conditions to obtain high-quality clean tags according to FastQC (V 0.10.1). Chimeric sequences were filtered using Verseach software ( $v$ 2.2.4). Sequences with $\geq 97 \%$ similarity were assigned to each representative sequence using the RDP (Ribosomal Database Project) classifier. Differences in dominant species among different groups were detected and multiple sequence alignments were conducted using PyNAST software, which revealed the phylogenetic relationships among different operational taxonomic units (OTUs). Abundance information for OTUs was normalized using a standard sequence number corresponding to the sample with the least sequences. Alpha diversity was determined by calculating four indices (Chao 1, Shannon's, Simpson's and Observed species) using QIIME (V 1.8.0). Differences in beta diversity (species complexity) among samples were detected by a principle co-ordinates analysis (PCoA) conducted using QIIME (V 1.8.0).

\section{Statistical Analysis}


One-way analysis of variance (ANOVA) was used to evaluate statistical significance of the effects of the two seeding patterns on soil properties, plant properties, relative abundance of dominant bacterial phyla, classes, and genera; bacterial community richness, diversity indices, and OTUs using SAS version 8.02 (SAS Institute, Cary, NC, USA). Unless otherwise stated, the significance level was $P \leq 0.05$. SigmaPlot was used to generate bar graphs. Pearson's correlation analysis was performed to detect relationships among soil and plant properties and soil fungal abundance, diversity, and relative abundance of dominant bacteria phyla and classes using Systat version 12.0 (Systat Software Inc., Chicago, IL, USA)., and the results were plotted using SigmaPlot.

\section{Results}

\section{Soil Water Content, Soil Salinity, Soil Temperature, and Seedling Emergence}

The seeding pattern significantly affected the soil water content, soil temperature, and number of emerged seedlings, but not soil EC (Fig. 3). At 4, 6, and 9 DAS, compared with the FL system, the FU system increased soil water content by $12.5 \%, 10.2 \%$, and $15.6 \%$, respectively; increased the number of emerged seedlings by $194.1 \%, 63.8 \%$, and $75.7 \%$, respectively; and decreased the soil temperature by $1.6^{\circ} \mathrm{C}, 1.1^{\circ} \mathrm{C}$, and $0.3^{\circ} \mathrm{C}$, respectively.

Inter-row and Inner-row Soil Moisture Content During the Vegetative Growth Stage

At 14 DAS, the seeding pattern significantly affected the inter-row soil moisture content, but not the inner-row moisture content (Fig. 4). At 14, 28, and 42 DAS, the inter-row soil moisture content was $35.11 \%$ higher, $33.44 \%$ higher, and $22.37 \%$ higher, respectively, than the inner-row soil moisture content in FU. However, the inter-row and inner-row soil water contents were not significantly different in FL. The seeding pattern significantly affected the inter-row soil water content. At 14,28 , and 42 DAS, the soil water content in FU was $24.38 \%$ higher, $56.77 \%$ higher, and $44.18 \%$ higher, respectively, in FU than in FL.

\section{Soil Bacterial Abundance And Community Diversity}

The seeding pattern had no significant effect on OTU richness, species richness (Chao1 index), and diversity (Shannon's index). However, the values of OTU richness, Chao1's, and Shannon's indices were higher in FU than in FL (Table 1).

Table 1

Number of sequences analyzed and observed bacterial community richness and diversity indexes (mean $\pm \mathrm{SE}, n=4$ ) in FU and FL (with clustering at $97 \%$ similarity levels).

\begin{tabular}{|lcccc|}
\hline & OTU richness & Observed species & Shannon & Chao 1 \\
\hline FU & $6870 \pm 199$ & $6418 \pm 87$ & $11.29 \pm 0.07$ & $8096 \pm 115$ \\
\hline FL & $6808 \pm 29$ & $6082 \pm 126$ & $11.11 \pm 0.11$ & $7681 \pm 113$ \\
\hline \multicolumn{2}{|l}{ Different superscript lower case letters indicate statistically significant differences at $P=0.05}$. \\
\hline
\end{tabular}

\section{Taxonomic Composition Of Soil Bacterial Communities}

Proteobacteria (relative abundance, 25.97-32.28\%), Actinobacteria (22.76-31.60\%), Acidobacteria (16.92-18.06\%), Gemmatimonadetes (6.54-8.57\%), and Chloroflexi (3.77-5.38\%), were the main bacteria phyla. Latescibacteria was a minor phylum, with relative abundance ranging from $0.021-0.028 \%$. Proteobacteria was the dominant bacterial phylum in FU, but Actinobacteria was the dominant bacterial phylum in FL. The relative abundance of Actinobacteria and Chloroflexi was significantly lower in FU than in FL. The relative abundance of other bacteria groups showed no significant difference between the two seeding patterns (Fig. 5).

The main bacterial classes were Actinobacteria (relative abundance, 21.78-29.85\%), Alphaproteobacteria (14.07-14.34\%), Acidobacteria (15.90-16.73\%), Betaproteobacteria (4.58-6.06\%), Gemmatimonadetes (4.57-5.59\%), and Deltaproteobacteria (4.18-5.77\%). Thermomicrobia was a minor class, with relative abundance ranging from $0.63-1.13 \%$. Actinobacteria was the dominant bacterial class in FU and FL. The relative abundance of Actinobacteria and Thermoleophilia was significantly lower in FU than in FL, while that of Deltaproteobacteria and Gammaproteobacteria was significantly higher in FU than in FL. The relative abundance of other bacterial classes did not differ significantly between the two seeding patterns (Fig. 6).

At the genus level, the relative abundance of unclassified Actinobacteria (Actinobacteria-unclassified) and unclassified Actinomycetales (Actinomycetales_unclassified) were lower in FU soil than in FL soil, while that of unclassified Betaproteobacteria (Betaproteobacteria_unclassified) was higher in FU than in FL (Fig. S1).

\section{Beta Diversity Analysis}

A PCoA was used to analyze beta diversity, to identify the differences in soil bacterial community composition between FU and FL (Fig. 7). At the OTU level, PCoA analyses showed that the FU soil samples clustered together, and were distinct from FL soil samples, indicating that their bacterial community compositions were dissimilar.

\section{Plant Height At Different Growth Stages}


The seeding pattern significantly affected alfalfa height in both 2019 and 2020 (Fig. 8). In 2019, plant height was 17.12\% higher in FU than in FL. In 2020, the plant height at the four measurement times was $30.79 \%, 27.59 \%, 16.89 \%$, and $14.82 \%$ higher in the FU system than in the FL system.

\section{Soil Properties In April 2020}

The soil available K, soil total N, and SOM were significantly higher in FU than in FL, while the ECe was lower in FU than in FL (Table 2). Soil available K, total $\mathrm{N}$, and SOM were $18.3 \%, 23.8 \%$, and $28.8 \%$ higher, respectively, in FU than in FL. The ECe was $25.7 \%$ lower in FU than in FL.

Table 2

Soil properties (0-15 cm depth) in FU and FL in April 2020

\begin{tabular}{|c|c|c|c|c|c|}
\hline Seeding pattern & Available $\mathrm{P}\left(\mathrm{mg} \mathrm{kg}^{-1}\right)$ & Available K (mg kg-1) & Total $\mathbf{N}\left(\mathrm{g} \mathrm{kg}^{-1}\right)$ & $\operatorname{ECe}\left(\mathrm{dSm}^{-1}\right)$ & $\operatorname{SOM}\left(\mathrm{g} \mathrm{kg}^{-1}\right)$ \\
\hline FU & $21.7 \pm 0.73 a$ & $280.7 \pm 8.57 a$ & $1.05 \pm 0.009 a$ & $12.8 \pm 0.61 b$ & $18.8 \pm 0.10 \mathrm{a}$ \\
\hline FL & $18.0 \pm 3.76 a$ & $237.3 \pm 5.82 b$ & $0.8 \pm 0.047 \mathrm{~b}$ & $17.3 \pm 1.43 a$ & $14.6 \pm 0.90 \mathrm{~b}$ \\
\hline
\end{tabular}

\section{Yield And Nutrient Contents Of First-cut Alfalfa In 2020}

The seeding pattern significantly affected alfalfa yield, and the contents of CP, DNF, ADF, ash, and ions in alfalfa plants (Table 3). Compared with FL, FU resulted in increased alfalfa yield, $\mathrm{CP}$ content, $\mathrm{K}^{+}$concentration, and $\mathrm{Ca}^{2+}$ concentration (by $37.4 \%, 3.56 \%, 33.2 \%$, and $17.8 \%$, respectively), and decreased contents of ash and $\mathrm{Na}^{+}$(by $7.71 \%$ and $19.01 \%$, respectively).

Table 3

Effects of seeding pattern on alfalfa yield, nutrient contents, and ion concentrations at the first cut in 2020.

\begin{tabular}{|c|c|c|c|c|c|c|c|c|}
\hline $\begin{array}{l}\text { Seeding } \\
\text { pattem }\end{array}$ & $\begin{array}{l}\text { Yield(DM } \\
\mathrm{kg} / \mathrm{hm}^{2} \text { ) }\end{array}$ & $\begin{array}{l}C P\left(g_{k g}^{-1}\right. \\
D M)\end{array}$ & $\begin{array}{l}\text { NDF }\left(\mathrm{g} \mathrm{kg}^{-1}\right. \\
\text { DM) }\end{array}$ & $\begin{array}{l}\text { ADF }\left(\mathrm{g} \mathrm{kg}^{-1}\right. \\
\text { DM) }\end{array}$ & $\begin{array}{l}\text { Ash } \\
\left(\mathrm{g} \mathrm{kg}^{-1}\right. \\
\mathrm{DM})\end{array}$ & $\begin{array}{l}\mathrm{K}^{+}\left(\mathrm{g} \mathrm{kg}^{-1}\right. \\
\mathrm{DM})\end{array}$ & $\begin{array}{l}\mathrm{Ca}^{2+} \\
\left(\mathrm{g} \mathrm{kg}^{-1}\right. \\
\mathrm{DM})\end{array}$ & $\begin{array}{l}\mathrm{Na}^{+} \\
\left(\mathrm{g} \mathrm{kg}{ }^{-1}\right. \\
\mathrm{DM})\end{array}$ \\
\hline FU & $7590 \pm 565.5 a$ & $180.5 \pm 1.84 a$ & $629.3 \pm 10.92$ & $456.3 \pm 25.4$ & $83.8 \pm 2.3 b$ & $14.03 \pm 0.24 a$ & $4.51 \pm 0.10 \mathrm{a}$ & $2.30 \pm 0.11 b$ \\
\hline FL & $5520 \pm 405.0 b$ & $174.3 \pm 1.67 b$ & $631.3 \pm 26.9$ & $464.3 \pm 21.5$ & $90.8 \pm 1.0 a$ & $10.53 \pm 0.69 b$ & $3.83 \pm 0.67 b$ & $2.84 \pm 0.04 a$ \\
\hline
\end{tabular}

Relationships Between Soil Bacterial Communities and Soil and Plant Properties

The Pearson's correlation analysis indicated that the Observed species index was positively correlated with soil available K, soil total N, SOM, and soil moisture content (Table 4). The Chao1 species richness index was positively correlated with soil available $\mathrm{K}$, soil total $\mathrm{N}$, and SOM, and negatively correlated with the shoot $\mathrm{Na}^{+}$concentration (Table 4). The relative abundance of Actinobacteria was highly correlated with alfalfa ash content, shoot Ca ${ }^{2+}$ concentration, and shoot $\mathrm{Na}^{+}$concentration, and negatively correlated with shoot $\mathrm{K}^{+}$concentration. The relative abundance of Chloroflexi was positively correlated with the shoot $\mathrm{Ca}^{2+}$ and $\mathrm{Na}^{+}$concentrations and negatively correlated with the soil available $\mathrm{P}$ concentration. The relative abundance of Deltaproteobacteria was positively correlated with soil total N, SOM, and alfalfa CP content. The relative abundance of Gammaproteobacteria was positively correlated with soil available K, soil total N, SOM, alfalfa CP content, and shoot $\mathrm{K}^{+}$concentration, and negatively correlated with shoot $\mathrm{Ca}^{2+}$ and $\mathrm{Na}^{+}$concentrations. The relative abundance of Thermoleophilia was positively correlated with shoot $\mathrm{Ca}^{2+}$ concentration and negatively correlated with shoot $\mathrm{K}^{+}$concentration. 
Table 4

Pearson's correlations coefficients between soil bacterial communities and soil and plant properties $(n=4)$ in twc

\begin{tabular}{|c|c|c|c|c|c|c|c|c|c|c|c|c|}
\hline & & $\begin{array}{l}\text { Available } \\
\mathrm{P}\end{array}$ & $\begin{array}{l}\text { Available } \\
\mathrm{K}\end{array}$ & $\begin{array}{l}\text { Total } \\
\mathbf{N}\end{array}$ & ECe & SOM & WET & $\mathrm{CP}$ & NDF & ADF & Ash & $\begin{array}{l}\mathrm{K}+ \\
\text { concentra }\end{array}$ \\
\hline & Valid tags & 0.315 & -0.618 & -0.514 & 0.448 & -0.485 & -0.370 & -0.578 & 0.466 & 0.263 & 0.136 & -0.593 \\
\hline & Observed-species & 0.175 & 0.924 ** & $0.908^{*}$ & -0.548 & $0.902^{\star}$ & $0.867^{*}$ & 0.717 & -0.451 & -0.223 & -0.728 & 0.712 \\
\hline & Diversity(Shannon) & -0.403 & 0.781 & 0.772 & -0.554 & 0.758 & 0.760 & 0.614 & -0.654 & -0.259 & -0.507 & 0.596 \\
\hline & OTU richness & 0.219 & 0.035 & 0.120 & 0.133 & 0.155 & 0.414 & -0.215 & 0.248 & 0.283 & -0.493 & -0.206 \\
\hline & Richness (Chao 1) & 0.179 & $0.963^{\star \star}$ & $0.893^{\star}$ & -0.504 & $0.890^{\star}$ & 0.811 & 0.736 & -0.097 & -0.098 & -0.810 & 0.795 \\
\hline phylum & Proteobacteria & 0.585 & 0.566 & 0.625 & -0.722 & 0.617 & 0.0564 & 0.762 & 0.0657 & -0.317 & -0.566 & 0.856 \\
\hline phylum & Acidobacteria & 0.193 & 0.474 & 0.598 & -0.173 & 0.626 & 0.686 & 0.287 & -0.0167 & -0.024 & $-0.825^{\star}$ & 0.243 \\
\hline phylum & Gemmatimonadetes & 0.114 & 0.672 & 0.554 & -0.569 & 0.525 & 0.206 & 0.712 & -0.138 & -0.245 & -0.244 & 0.802 \\
\hline phylum & Chloroflexi & $-0.858^{\star}$ & -0.625 & -0.594 & 0.555 & -0.603 & -0.317 & -0.524 & -0.528 & -0.114 & 0.798 & -0.728 \\
\hline phylum & Bacteroidetes & 0.531 & -0.167 & -0.210 & -0.541 & -0.211 & -0.264 & -0.285 & 0.388 & 0.491 & -0.023 & 0.0735 \\
\hline class & Actinobacteria & -0.617 & -0.733 & -0.791 & 0.752 & -0.793 & -0.382 & -0.751 & -0.108 & 0.178 & $0.843^{*}$ & $-0.872^{\star}$ \\
\hline class & Alphaproteobacteria & 0.517 & -0.678 & -0.708 & 0.229 & -0.709 & $-0.877 *$ & -0.459 & 0.638 & 0.239 & 0.535 & -0.336 \\
\hline class & Acidobacteria & 0.092 & 0.481 & 0.606 & -0.431 & 0.629 & 0.711 & 0.245 & -0.191 & 0.0426 & -0.813 & 0.283 \\
\hline class & Betaproteobacteria & 0.803 & 0.018 & 0.024 & 0.117 & 0.0351 & -0.296 & 0.199 & 0.718 & -0.027 & -0.021 & 0.221 \\
\hline class & Gemmatimonadetes & -0.092 & 0.708 & 0.557 & -0.556 & 0.528 & 0.405 & 0.596 & -0.257 & -0.121 & -0.242 & 0.705 \\
\hline class & Deltaproteobacteria & -0.111 & 0.745 & $0.861^{*}$ & -0.539 & $0.849 *$ & 0.426 & $0.945^{\star \star}$ & -0.586 & -0.677 & -0.561 & 0.796 \\
\hline class & Gammaproteobacteria & 0.287 & $0.894^{*}$ & $0.899 *$ & -0.809 & $0.886^{\star}$ & 0.502 & $0.899 *$ & -0.197 & -0.308 & -0.743 & $0.981^{\star \star}$ \\
\hline class & Thermoleophilia & -0.693 & -0.797 & -0.733 & $0.868^{*}$ & -0.729 & -0.456 & -0.624 & -0.281 & -0.125 & -0.812 & $-0.914^{\star}$ \\
\hline
\end{tabular}

Pairs of variables with positive correlation coefficients and $P$ values below 0.05 tend to increase together. For the pairs with negative correlation coefficients $c$ the other increases. For pairs with $\mathrm{P}$ value greater than 0.05 , there is no significant relationship between the two variables.

\section{Relationships Between Alfalfa Yield and Soil and Plant Properties in the Second Growth Year}

The Pearson's correlation analysis indicated that alfalfa yield was positively correlated with the number of emerged seedlings, and the contents of soil available $\mathrm{K}$, soil total $\mathrm{N}$, and SOM. In addition, alfalfa yield was positively correlated with the shoot $\mathrm{K}^{+}$concentration and negatively correlated with the shoot $\mathrm{Na}^{+}$concentration (Table 5).

Table 5

Pearson correlations coefficients between alfalfa yield and soil and plant properties $(n=4)$ in two crop systems.

\begin{tabular}{|c|c|c|c|c|c|c|c|c|c|c|c|c|c|}
\hline & $\begin{array}{l}\text { Available } \\
\text { P }\end{array}$ & $\begin{array}{l}\text { Available } \\
\text { K }\end{array}$ & $\begin{array}{l}\text { Total } \\
\mathbf{N}\end{array}$ & $\mathrm{ECe}$ & SOM & WET & $\mathrm{CP}$ & NDF & ADF & Ash & $\begin{array}{l}\mathrm{K}^{+} \\
\text {concentration }\end{array}$ & $\begin{array}{l}\mathrm{Ca}^{2+} \\
\text { concentration }\end{array}$ & $\begin{array}{l}\mathrm{Na}^{+} \\
\text {concentrat }\end{array}$ \\
\hline yield & 0.239 & $0.974^{\star *}$ & $0.892^{*}$ & 0.106 & $0.883^{*}$ & 0.751 & 0.798 & -0.0547 & -0.128 & -0.767 & $0.888^{*}$ & -0.689 & $-0.891^{*}$ \\
\hline
\end{tabular}

Pairs of variables with positive correlation coefficients and $\mathrm{P}$ values below 0.05 tend to increase together. For the pairs with negative correlation coefficients $c$ below 0.05 , one variable tends to decrease while the other increases. For pairs with $\mathrm{P}$ value greater than 0.05 , there is no significant relationship between the 1

\section{Discussion}

\section{Effects of FU on Seedling Emergence and Soil Properties at the Seedling Stage}

Seedling emergence and establishment are key processes in alfalfa production (Kunzova and Hejcman 2009). In our study, FU significantly increased the number of emerged seedlings, and this was positively correlated with alfalfa yield (Table 5). Soil moisture is one of the main factors affecting seed emergence and plant growth and development (Yi et al., 2010; Silvente et al., 2012, Liao, 2021). Even a small change in soil water storage can affect crop productivity (Liu et al., 2010a,b). The higher seedling emergence in the FU system than in the FL system was mainly due to the higher soil moisture content in the FU system. Ridge-furrow cropping is a well-known soil-water conservation practice used in crop production. In our study, the water content in the furrow during the seed germination stage was increased in the FU system, consistent with the results of previous studies (Li et al. 2007; Liao et al. 2019; Suo et al., 2019; Zhang et al., 2011; Zribi et al., 2015). The higher soil moisture content in the furrow was mainly because the soil moisture content was higher in the top $15 \mathrm{~cm}$ soil layer (the ridge height was $15 \mathrm{~cm}$ ) than in the surface soil after the rainy season in early fall. It was not due to rainwater harvesting, because there was no rainfall during the seedling period in our experiment. In our study, the FU system reduced the soil temperature at the seedling stage, because the higher soil moisture in the FU treatment reduced the thermal conductivity compared with that of soil in FL. The lower soil temperature did not inhibit seed germination, because alfalfa 
seeds begin germinating shortly after planting, when soil temperatures are above $18^{\circ} \mathrm{C}$ and adequate moisture is present (Summers and Putna 2008 ). In our study, FU did not significantly affect the soil salinity at the seedling stage, probably because alfalfa seeds were planted after the rainy season in early fall. At this time, the salt had been leached from the soil by rain, so that the salinity levels in topsoil were low both in FU and FL.

\section{Effects Of Fu On Soil Bacterial Diversity}

The PCoA plots show that the bacterial community composition was significantly different between FU and FL (Fig. 7), indicating that the FU system affected the bacterial abundance and diversity at the seedling stage. As indicated by the higher Chao1 value, the FU system increased the bacterial richness compared with that in the FL system (Table 1). Consistent with this, a previous study found that agricultural management influences the soil microbial community and composition (Chen et al. 2014). In the present study, the higher bacterial richness in the FU system may have resulted from the higher soil moisture content. Previous studies have shown that soil moisture strongly affects soil bacteria (Bainard et al. 2016; Nguyen et al. 2018) and that higher soil moisture content can favor bacterial growth (Nakamura et al. 2003). Interestingly, neither our study nor a previous study (Yang et al. 2019) detected a strong relationship between soil salinity and soil bacterial abundance. This might be because there were only small variations in salinity at the seedling stage, since alfalfa seeds were sown after the rainy season when much of the salt had been leached from the soil.

In the present study, high-throughput sequencing revealed that the dominant bacterial phyla in saline soils were Proteobacteria, Actinobacteria, Acidobacteria, Gemmatimonadetes, and Chloroflexi (Fig. 5). These five phyla accounted for an average $85.45 \%$ and $86.41 \%$ of total bacterial sequences in FU and FL, respectively. This soil bacterial community composition differs from that detected in other agro-ecosystems (Chen et al. 2014). Among these taxa, Chloroflexi, a representative oligotrophic taxa that favors nutrient-poor conditions, was less abundant in FU than in FL. In contrast, the relative abundance of copiotrophic taxa, including Proteobacteria, was higher in FU than in FL. Proteobacteria, especially Betaproteobacteria, are copiotrophic and favor nutrient-rich conditions with a high C content (Fierer et al. 2007; Newton and McMahon 2011; Philippot et al. 2013; Wang et al. 2017). Unfortunately, we only analyzed the background surface soil, rather than soil samples collected from plant rows in the FU and FU treatments during the seedling period. Thus, the increased abundance of Proteobacteria in FU may be because of the increased supply of nutrient substrates that improved their growth. Bacteroidetes are copiotrophic and saprophytic bacteria (Fierer et al. 2007) that live in anaerobic environments (Xu et al. 2017). In our study, the abundance of Bacteroidetes was increased in FU. This may have been because of the higher SOM in FU than in FL. In addition, increased soil moisture favors the growth of Bacteroidetes (Xu et al. 2017).

\section{Effects of FU on Soil Properties in the Second Year (2020)}

Compared with FL, FU reduced the soil salinity in plant belts in the second growth year, consistent with the results of a previous study (Dong et al. 2010). The salinity level was lower in furrows in FU than in seeding rows in FL. This is because salinity moves upwards along a capillary gradient in the spring when there is little rainfall, and accumulates on the surface of the soil ridges. A previous study showed that FU can lead to a heterogeneous distribution of salts in the plant root zone (Dong et al. 2010), and our previous study showed that alfalfa plants grow better with heterogeneous salinity than with uniform salinity in the root zone (Sun et al. 2016). The results of the present study show that FU alleviated salt stress in alfalfa in the second growth year.

In this study, the FU system significantly affected the soil physico-chemical properties and enhanced the contents of available nutrients in soil (Table 2), similar to the results of a previous study (Sun et al. 2017a). Our results showed that soil available K, total N, and SOM were significantly correlated with Observed-species and richness (Chao 1) indexes of soil bacterial communities. In our study, the Observed-species and Chao 1 index values were higher in FU than in FL. Previous studies have indicated that soil moisture content and other physicochemical properties affect microbial populations and community composition (Nguyen et al. 2018; Li and Sarah 2003; Sing et al. 2013; ), which in turn enhances the formation and decomposition of organic matter (Nair and Ngouajio 2012; Jing et al. 2013). In our study, the FU system enhanced the SOM, soil total N, and soil available K in the second growth year, possibly as a result of changes in soil microbial populations and community composition.

\section{Effects Of Fu On Alfalfa Yield And Quality}

The FU system increased alfalfa yield compared with the traditional FL system. The yield of alfalfa in the first cut of the second growth year was $37.4 \%$ higher in FU than in FL. Previous studies have also reported that FU systems can improve plant production (Li et al. 2001; Li et al. 2013). In our study, Pearson's correlation analyses showed that alfalfa yield was positively correlated with seedling emergence, soil available $\mathrm{K}$, soil total $\mathrm{N}$, SOM, and shoot $\mathrm{K}^{+}$ concentration, and negatively correlated with shoot $\mathrm{Na}^{+}$concentration (Table 5), indicating that the increased yield was due to high emergence during the seedling stage, and greater nutrient availability for alfalfa uptake. However, there was no significant relationship between soil ECe and yield (Table 5). Our results show that soil salinity was lower in FU than in FL, and that the alfalfa shoot $\mathrm{Na}^{+}$concentration was lower in FU than in $\mathrm{FL}$, suggesting that $\mathrm{FU}$ alleviated salinity and improved alfalfa production. Similar results were found in a previous study (Dong et al. 2010). During the whole plant growth period in our study, plant height was higher in FU than in FL, and this is an important yield component for alfalfa.

Notably, FU improved alfalfa quality compared with FL. For the first cut of alfalfa, the CP content was higher and NDF, ADF, and ash contents in alfalfa plants were lower in FU than in FL in the second year. The results of the Pearson's correlation analyses revealed that the alfalfa CP content was positively correlated with soil total $\mathrm{N}$ and SOM. Thus, the increased alfalfa CP in FU was related to the increased soil total N and SOM in the FU system, while the decreased ash content in FU was due to higher soil available K, total N, and SOM. An important aspect of the improved alfalfa quality in FU was the higher left-stem height, because the CP was lower and NDF, ADF, and ash contents were higher at the basal part of stem.

In conclusion, compared with FL, FU increased the soil moisture content and seedling emergence and altered the soil bacterial community during the seedling stage. The FU system also increased the available soil nutrient contents and decreased soil salinity at the returning green stage in the second growth year. 
Compared with FL, the FU system resulted in significant improvements in alfalfa plant height, yield, and quality, and decreased salt injury. The improved yield was due to higher soil moisture content, higher seedling emergence, higher contents of soil available nutrients and SOM, and lower salt content in the plant rows in spring of the second growth year. Enhanced $\mathrm{K}^{+}$and reduced $\mathrm{Na}^{+}$accumulation in shoots may be mechanisms to avoid salinity stress. Overall, our results show that specific cultural practices such as FU with sowing in early fall have immense potential for alleviating salt stress and improving alfalfa productivity and quality in saline fields.

\section{Declarations}

\section{Acknowledgments}

This work was supported by Natural Science Foundation of Inner Mongolia (Grant no. 2018MS03028), Science and Technology Project from Inner Mongolia (Grant no. 2019GG260) and Agricultural Science and Technology Innovation Program of CAAS (No.27-GRI-01). We thank Gao Feixiang for providing us weather date. We thank Jennifer Smith, PhD, from Liwen Bianji (Edanz) (www.liwenbianji.cn/) for editing the English text of a draft of this manuscript.

\section{Conflict of interest}

All authors declare that they have no conflict of interest.

\section{Author Contributions}

$\mathrm{KJ}$ and JS conceived and designed the research. JS, JZ, LY, TZ and YW conducted the experiment and collected field data, JS and JZ analyzed the data. KJ and JS wrote the manuscript. All authors reviewed and edited the manuscript.

\section{Data Availability}

All data generated of analysed during this study are included in this published article and its supplementary information files.

\section{References}

1. Allen SG, Dobrenz AK, Schonhorst MH, Stoner JE (1985) Heritability of Nacl Tolerance in Germinating Alfalfa Seeds. Aoron J 77:99-101. https://doi.org/10.2134/agronj1985.00021962007700010023x

2. Ashraf M, Mcneilly T, Bradshaw AD (1987) Selection and Heritability of Tolerance to Sodium-Chloride in Four Forage Species. Crop Sci 27:232-234. https://doi.org/10.2135/cropsci1987.0011183X002700020021x

3. Bainard LD, Hamel C, Gan Y (2016) Edaphic properties override the influence of crops on the composition of the soil bacterial community in a semiarid agroecosystem. Appl Soil Ecol 105:160-168. https://doi.org/10.1016/j.apsoil.2016.03.013

4. Battin TJ, Kaplan LA, Newbold JD, Hansen CME (2003) Contributions of microbial biofilms to ecosystem processes in stream mesocosms. Nature 426:439-442. https://doi.org/10.1038/nature02152

5. Bao SD (2005) Soil Agrochemical Analysis. China Agriculture Press, Beijing

6. Chen Y, Wen X, Sun Y, Zhang J, Wu W, Liao Y (2014) Mulching practices altered soil bacterial community structure and improved orchard productivity and apple quality after five growing seasons. Sci Hortic 172:248-257. https://doi.org/10.1016/j.scienta.2014.04.010

7. Chi Z, Wang W, Li H, Wu H, Yan B (2021) Soil organic matter and salinity as critical factors affecting the bacterial community and function of Phragmites australis dominated riparian and coastal wetlands. Sci Total Environ 762. https://doi.org/10.1016/j.scitotenv.2020.143156

8. Cuello JP, Hwang HY, Gutierrez J, Kim SY, Kim PJ (2015) Impact of plastic film mulching on increasing greenhouse gas emissions in temperate upland soil during maize cultivation. Appl Soil Ecol 91:48-57. https://doi.org/10.1016/j.apsoil.2015.02.007

9. Deinlein U, Stephan AB, Horie T, Luo W, Xu G, Schroeder JI (2014) Plant salt-tolerance mechanisms. Trends Plant Sci 19:371-379. https://doi.org/10.1016/j.tplants.2014.02.001

10. Devkota M, Martius C, Gupta RK, Devkota KP, Mcdonald AJ, Lamers JPA (2015) Managing soil salinity with permanent bed planting in irrigated production systems in Central Asia. https://doi.org/10.1016/j.agee.2014.12.006. Agric Ecosyst Environ

11. Dong H, Kong X, Luo Z, Li W, Xin C (2010) Unequal salt distribution in the root zone increases growth and yield of cotton. Eur J Agron 33:285-292. https://doi.org/10.1016/j.eja.2010.08.002

12. Dong H, Li W, Tang W, Zhang D (2009) Early plastic mulching increases stand establishment and lint yield of cotton in saline fields. Field Crops Res 111:269-275. https://doi.org/10.1016/j.fcr.2009.01.001

13. Esechie HA, Al-Barhi B, Al-Gheity S, Al-Khanjari S (2002) Root and shoot growth in salinity-stressed alfalfa in response to nitrogen source. J Plant Nutr 25:2559-2569. https://doi.org/10.1081/PLN-120014713

14. Fierer N, Bradford MA, Jackson RB (2007) Toward an ecological classification of soil bacteria. Ecology 88:1354-1364. https://doi.org/10.1890/05-1839

15. Gao Y-c, Wang J-n, Guo S-h, Hu Y-L, Li T-t, Mao R, Zeng D-H (2015) Effects of salinization and crude oil contamination on soil bacterial community structure in the Yellow River Delta region, China. Appl Soil Ecol 86:165-173. https://doi.org/10.1016/j.apsoil.2014.10.011

16. Gu Y-J, Han C-L, Kong M, Shi X-Y, Zdruli P, Li F-M (2018) Plastic film mulch promotes high alfalfa production with phosphorus-saving and low risk of soil nitrogen loss. Field Crop Res 229:44-54. https://doi.org/10.1016/j.fcr.2018.09.011 
17. Guo X-p, Lu D-p, Niu Z-s, Feng J-n, Chen Y-r, Tou F-y, Liu M, Yang Y (2018) Bacterial community structure in response to environmental impacts in the intertidal sediments along the Yangtze Estuary, China. Mar Pollut Bul 126:141-149. https://doi.org/10.1016/j.marpolbul.2017.11.003

18. Jing T, Lu S, Fan M, Li X, Kuzyakov Y (2013) Labile soil organic matter fractions as influenced by non-flooded mulching cultivation and cropping season in rice-wheat rotation. Eur J Soil Biol 56:19-25. https://doi.org/10.1016/j.ejsobi.2013.02.001

19. Jurburg SD, Natal-da-Luz T, Raimundo J, Morais PV, Sousa JP, van Elsas JD, Salles JF (2018) Bacterial communities in soil become sensitive to drought under intensive grazing. Sci Total Environ 618:1638-1646. https://doi.org/10.1016/j.scitotenv.2017.10.012

20. Kargas G, Kerkides P, Seyfried M, Sgoumbopoulou A (2011) WET Sensor Performance in Organic and Inorganic Media with Heterogeneous Moisture Distribution. Soil Sci Soc Am J 75:1244-1252. https://doi.org/10.2136/sssaj2010.0238

21. Krishnamoorthy U, Muscato TV, Sniffen CJ, Van Soest PJ (1982) Nitrogen Fractions in Selected Feedstuffs. J Dairy Sci 65:217-225. https://doi.org/10.3168/jds.S0022-0302(82)82180-2

22. Kunzova E, Hejcman M (2009) Yield development of winter wheat over 50 years of FYM, N, P and K fertilizer application on black earth soil in the Czech Republic. Field Crops Res 111:226-234. https://doi.org/10.1016/j.fcr.2008.12.008

23. Li R, Hou X, Jia Z, Han Q, Ren X, Yang B (2013) Effects on soil temperature, moisture, and maize yield of cultivation with ridge and furrow mulching in the rainfed area of the Loess Plateau, China. Agric Water Manage 116:101-109. https://doi.org/10.1016/j.agwat.2012.10.001

24. Li X, Sarah P (2003) Enzyme activities along a climatic transect in the Judean Desert. CATENA 53:349-363. https://doi.org/10.1016/S03418162(03)00087-0

25. Li X, Su D, Yuan Q (2007) Ridge-furrow planting of alfalfa (Medicago sativa L.) for improved rainwater harvest in rainfed semiarid areas in Northwest China. Soil Tillage Res 93:117-125. https://doi.org/10.1016/j.still.2006.03.022

26. Li XY, Gong JD, Gao QZ, Li FR (2001) Incorporation of ridge and furrow method of rainfall harvesting with mulching for crop production under semiarid conditions. Agri Water Manag 50:173-183. https://doi.org/10.1016/S0378-3774(01)00105-6

27. Li XY, Gong JD, Wei XH (2000) In-situ rainwater harvesting and gravel mulch combination for corn production in the dry semi-arid region of China. J Arid Environ 46:371-382. https://doi.org/10.1006/jare.2000.0705

28. Liao Y, Cao HX, Xue WK, Liu X (2021) Effects of the combination of mulching and deficit irrigation on the soil water and heat, growth and productivity of apples. Agric Water Manage 243:106482. https://doi. org/10.1016/j.agwat.2020.106482

29. Ling N, Chen D, Guo H, Wei J, Bai Y, Shen Q, Hu S (2017) Differential responses of soil bacterial communities to long-term N and P inputs in a semi-arid steppe. Geoderma 292:25-33. https://doi.org/10.1016/j.geoderma.2017.01.013

30. Liu XE, Li XG, Hai L, Wang YP, Li FM (2014) How efficient is film fully-mulched ridge-furrow cropping to conserve rainfall in soil at a rainfed site? Field Crop Res 169:107-115. https://doi.org/10.1016/j.fcr.2014.09.014

31. Liu Y, Li S, Chen F, Yang S, Chen X (2010a) Soil water dynamics and water use efficiency in spring maize (Zea mays L.) fields subjected to different water management practices on the Loess Plateau, China. Agric Water Manag 97:769-775. https://doi.org/10.1016/j.agwat.2010.01.010

32. Liu Y, Yang S, Li S, Chen X, Chen F (2010b) Growth and development of maize (Zea mays L.) in response to different field water management practices: Resource capture and use efficiency. Agr Forest Meteorol 150:606-613. https://doi.org/10.1016/j.agrformet.2010.02.003

33. Meiri A, Plaut Z (1985) Crop production and management under saline conditions. Plant Soil 89:253-271. https://doi.org/10.1007/bf02182246

34. Latrach L, Farissi M, Mouradi M, Makoudi B, Bouizgaren A, Ghoulam C (2014) Growth and nodulation of alfalfa-rhizobia symbiosis under salinity: electrolyte leakage, stomatal conductance, and chlorophyll fluorescence. Turk J Agric For 38:320-326. https://doi.org/10.3906/tar-1305-52

35. Nair A, Ngouajio M (2012) Soil microbial biomass, functional microbial diversity, and nematode community structure as affected by cover crops and compost in an organic vegetable production system. Appl Soil Ecol 58:45-55. https://doi.org/10.1016/j.apsoil.2012.03.008

36. Nakamura A, Tun CC, Asakawa S, Kimura M (2003) Microbial community responsible for the decomposition of rice straw in a paddy field: estimation by phospholipid fatty acid analysis. Biol Fertil Soils 38:288-295. https://doi.org/10.1007/s00374-003-0658-6

37. Newton RJ, McMahon KD (2011) Seasonal differences in bacterial community composition following nutrient additions in a eutrophic lake. Environ Microbiol 13:887-899. https://doi.org/10.1111/j.1462-2920.2010.02387.x

38. Nguyen LTT, Osanai Y, Lai K, Anderson IC, Bange MP, Tissue DT, Singh BK (2018) Responses of the soil microbial community to nitrogen fertilizer regimes and historical exposure to extreme weather events: Flooding or prolonged-drought. Soil Bio Biochem 118:227-236.

https://doi.org/10.1016/j.soilbio.2017.12.016

39. Nie Y, Wang M, Zhang W, Ni Z, Hashidoko Y, Shen W (2018) Ammonium nitrogen content is a dominant predictor of bacterial community composition in an acidic forest soil with exogenous nitrogen enrichment. Sci Total Environ 624:407-415. https://doi.org/10.1016/j.scitotenv.2017.12.142

40. Noble CL, Halloran GM, West DW (1984) Identification and selection for salt tolerance in lucerne (Medicago sativa L.). Aust J Agric Res 35:239-252. https://doi.org/10.1071/ar9840239

41. Philippot L, Raaijmakers JM, Lemanceau P, van der Putten WH (2013) Going back to the roots: the microbial ecology of the rhizosphere. Nat Rev Microbiol 11:789-799. https://doi.org/10.1038/nrmicro3109

42. Robertson JB, Van Soest PJ (1981) The detergent system of analysisi and its application to human foods.. In: In: James WPT, Theander O (eds) The Analysis of Dietary Fiber in Food. Marcel Dekker, NY, NY, USA, pp 123-158

43. Semrau JD (2011) Current knowledge of microbial community structures in landfills and its cover soils. Appl Microbiol Biot 89:961-969. https://doi.org/10.1007/s00253-010-3024-2

44. Silvente S, Sobolev AP, Lara M (2012) Metabolite Adjustments in Drought Tolerant and Sensitive Soybean Genotypes in Response to Water Stress. PLoS ONE 7:e38554. https://doi.org/10.1371/journal.pone.0038554

Page $10 / 17$ 
45. Sing HV, Station R, SKUASTK (2013) Soil Carbon Sequestration and Rhizospheric Microbial Population in Apricot Orchards Following Plastic Film Mulching Under Cold Arid Region. International Journal of Horticulture 3. https://doi.org/10.5376/ijh.2013.03.0008

46. Summers CG, Putna DH (2008) Irrigated Alfalfa Management for Mediterranean and Desert Zones. University of California Agriculture and Natural Resources, California

47. Sun CT, Feng D, Mi ZR, Li CX, Zhang JP, Gao Y, Sun JS (2017a) Impacts of Ridge-Furrow Planting on Salt Stress and Cotton Yield under Drip Irrigation. Water 9:49. https://doi.org/10.3390/w9010049

48. Sun J, Yang G, Zhang W, Zhang Y (2016) Effects of heterogeneous salinity on growth, water uptake, and tissue ion concentrations of alfalfa. Plant Soil 408:211-226. https://doi.org/10.1007/s11104-016-2922-1

49. Sun J, Yu L, Zhao J, Liu H, Zhang Y (2017b) Effects of Heterogeneous Root Zone Salinity on Plant Growth and Ion Characteristic in Alfalfa. Scientia Agricultura Sinica 50:4329-4306. https://doi.org/10.3864/j.issn.0578-1752.2017.22.006

50. Suo GD, Xie YS, Zhang Y, Luo H (2019) Long-term effects of different surface mulching techniques on soil water and fruit yield in an apple orchard on the Loess Plateau of China. Sci Hortic 246:643-651. https://doi.org/10.1016/j.scienta.2018.11.028

51. Van Soest PJ, Robertson JB, Lewis BA (1991) Methods for dietary fiber, neutral detergent fiber, and nonstarch polysaccharides in relation to animal nutrition. J Dairy Sci 74:3583-3897. https://doi.org/10.3168/jds.S0022-0302(91)78551-2

52. Wakelin SA, Colloff MJ, Harvey PR, Marschner P, Gregg AL, Rogers SL (2007) The effects of stubble retention and nitrogen application on soil microbial community structure and functional gene abundance under irrigated maize. Fems Microbiol Ecol 59:661-670. https://doi.org/10.1111/j.15746941.2006.00235.x

53. Wang J, Song Y, Ma T, Raza W, Li J, Howland JG, Huang Q, Shen Q (2017) Impacts of inorganic and organic fertilization treatments on bacterial and fungal communities in a paddy soil. Appl Soil Ecol 112:42-50. https://doi.org/10.1016/j.apsoil.2017.01.005

54. Xiong X, Wei Y-q, Chen J-h, Liu N, Zhang Y-j (2020) Transcriptome analysis of genes and pathways associated with salt tolerance in alfalfa under nonuniform salt stress. Plant Physiol Biochemistry 151:323-333. https://doi.org/10.1016/j.plaphy.2020.03.035

55. Xu S, Lu W, Liu Y, Ming Z, Liu Y, Meng R, Wang H (2017) Structure and diversity of bacterial communities in two large sanitary landfills in China as revealed by high-throughput sequencing (MiSeq). Waste Manage 63:41-48. https://doi.org/10.1016/j.wasman.2016.07.047

56. Yang W, Jeelani N, Zhu ZH, Luo YQ, Cheng XL, An SQ (2019) Alterations in soil bacterial community in relation to Spartina alterniflora Loisel. invasion chronosequence in the eastern Chinese coastal wetlands. Appl Soil Ecol 135:38-43. https://doi.org/10.1016/j.apsoil.2018.11.009

57. Yang Y, Dou Y, An S (2018) Testing association between soil bacterial diversity and soil carbon storage on the Loess Plateau. Sci Total Environ 626:4858. https://doi.org/10.1016/j.scitotenv.2018.01.081

58. Zribi W, Aragues R, Medina E, Faci JM (2015) Efficiency of inorganic and organic mulching materials for soil evaporation control. Soil Tillage Res 148:4045. https://doi.org/10.1016/j.still.2014.12.003

\section{Figures}




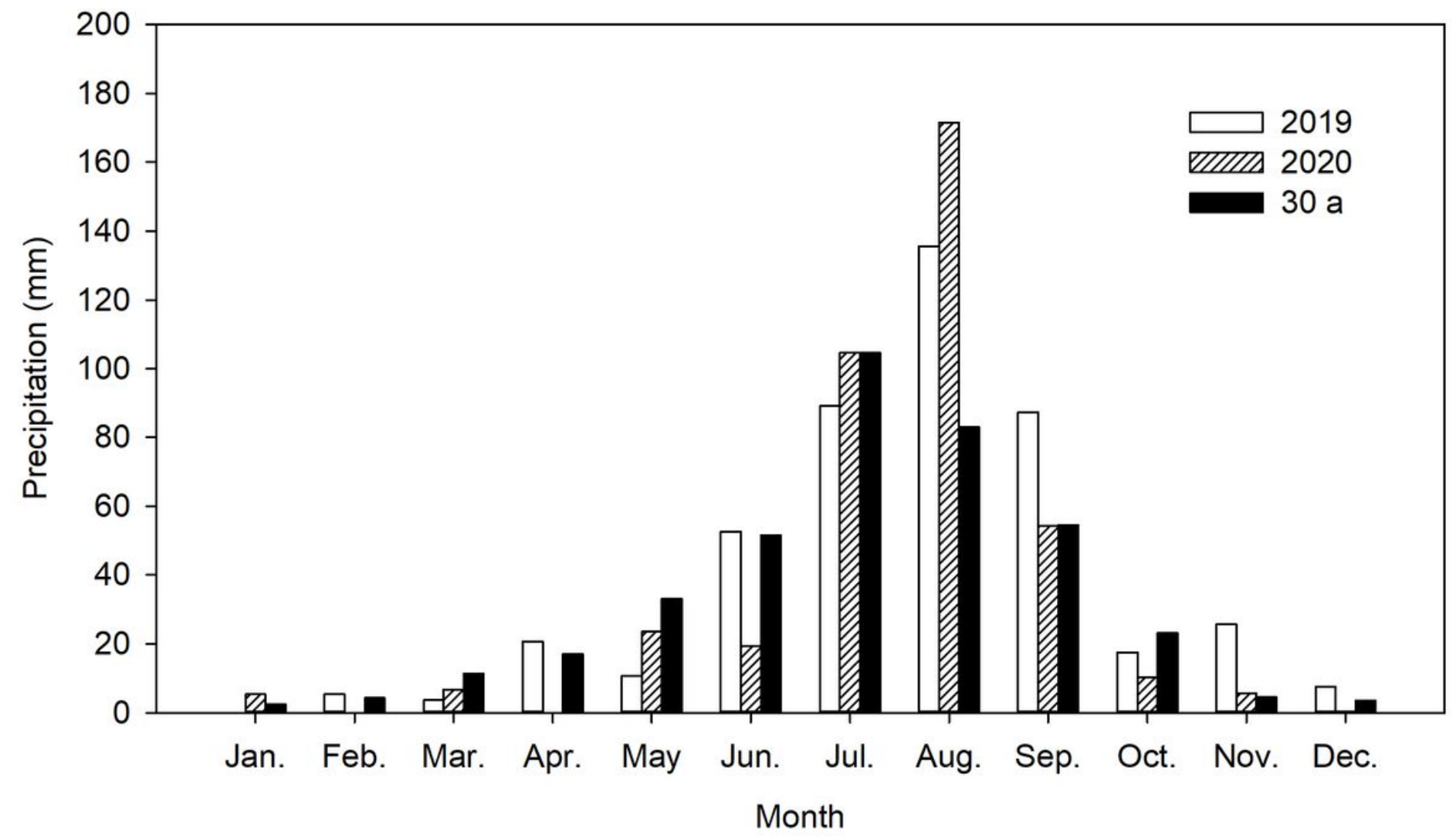

Figure 1

Precipitation distribution from 2019 to 2020 and 30-year average (30 a) at the experimental site.

(a)

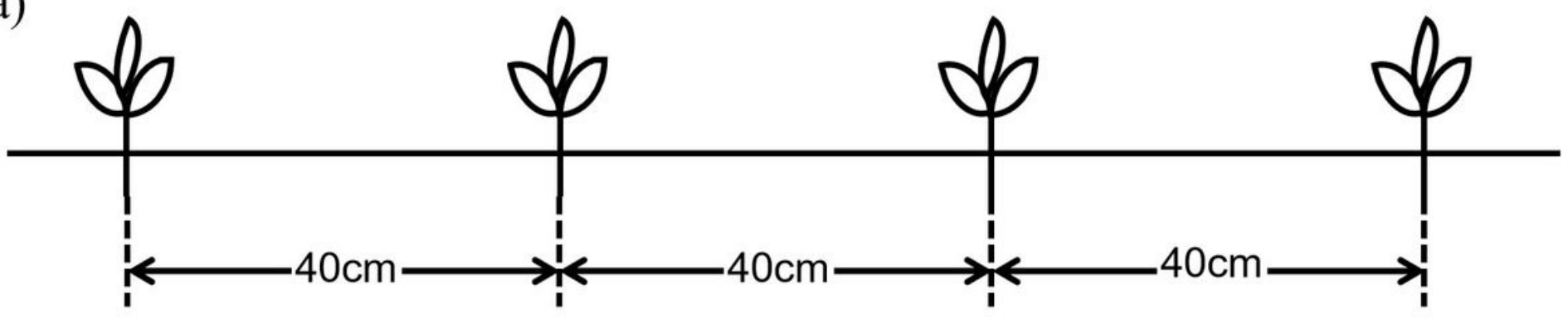

(b)

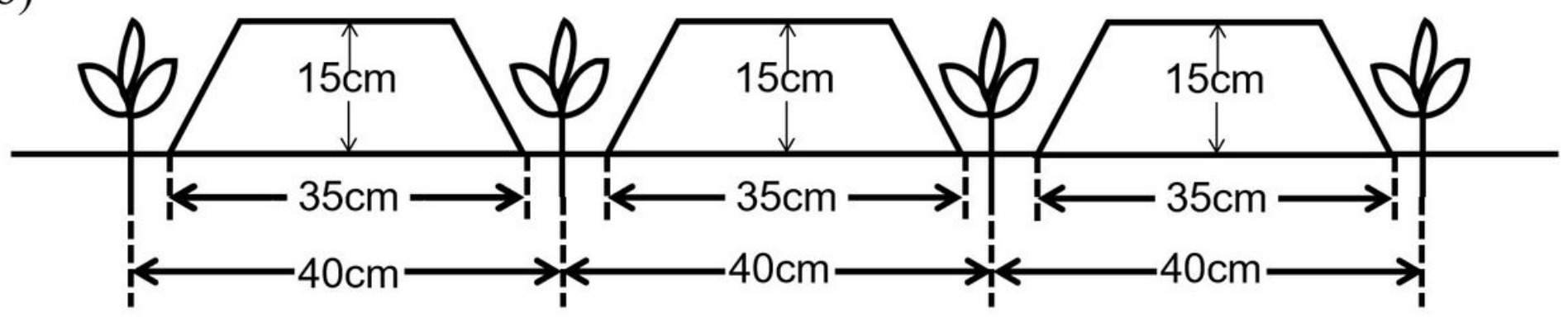

Figure 2

Schematic diagram of (a) flat-bed seeding (FL) and (b) furrow-bed seeding (FU) systems. 

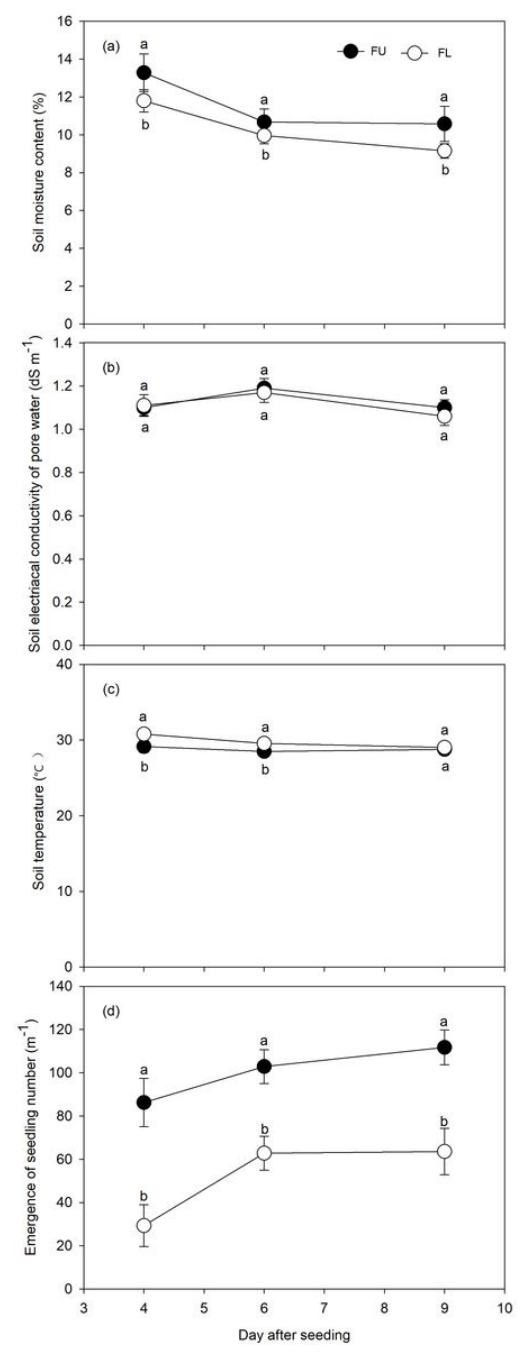

\section{Figure 3}

Effects of FU and FL on Soil moisture content (a), soil electrical conductivity of pore water (b), soil temperature (c), and number of emerged seedlings(d) of alfalfa 4, 6, and 9 days after seeding. during the seedling stage. Solid circles show FU treatment; hollow circles show FL treatment. Values are means ( $n=4$ ) \pm SE. Same lowercase capital letters indicate no significant difference between two seeding patterns at $\mathrm{P} \leq 0.05$.

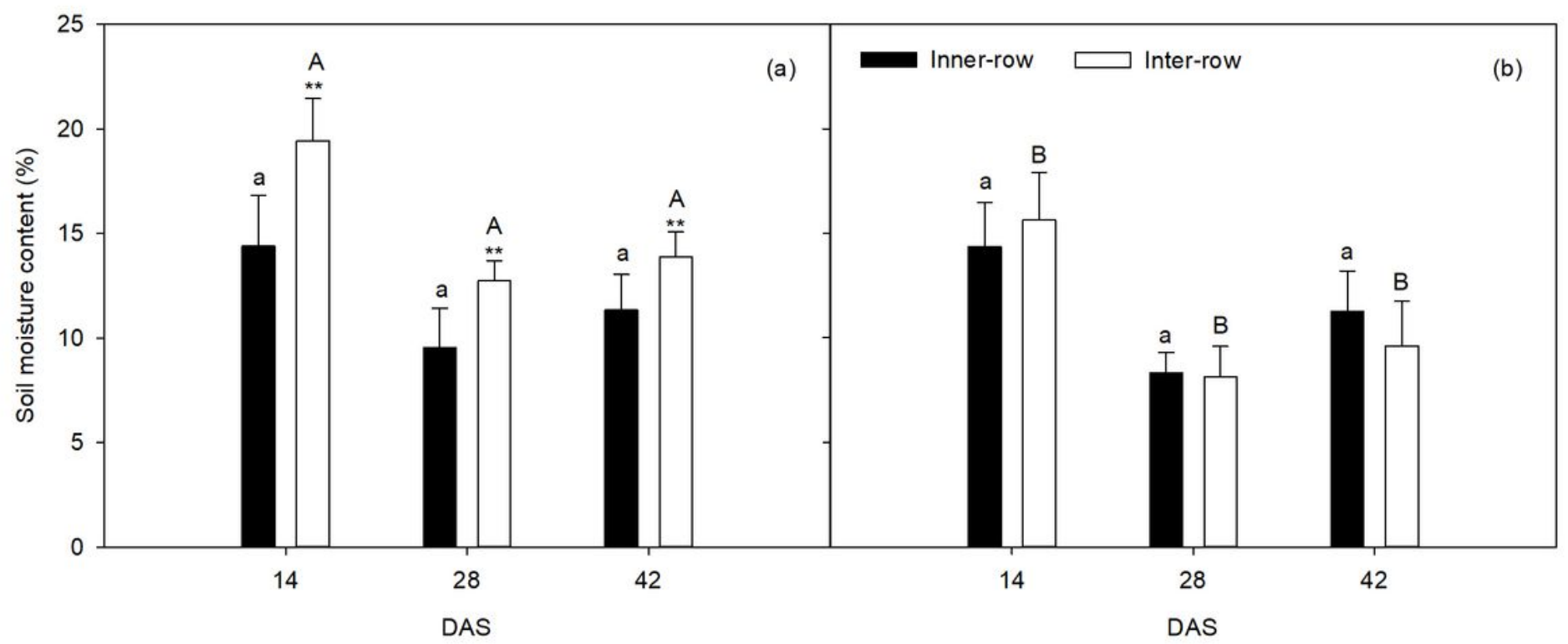

Figure 4 
Effects of FU (a) and FL (b) on soil water content of ridge/inter-row and furrow/inner-row at 14, 28, and 42 days after seeding (DAS). Solid bars show innerrow soil water content; hollow bars show inter-row soil water content. Values are means $(n=4) \pm S E$. Asterisks above symbols indicate significant differences in soil water content between inter-row and inner-row at $P \leq 0.05$. Same capital letters indicate no significant difference in inter-row soil water content between two seeding patterns at $P \leq 0.05$. Same lowercase capital letters indicate no significant difference in inner-row soil water content between two seeding patterns at $\mathrm{P} \leq 0.05$.
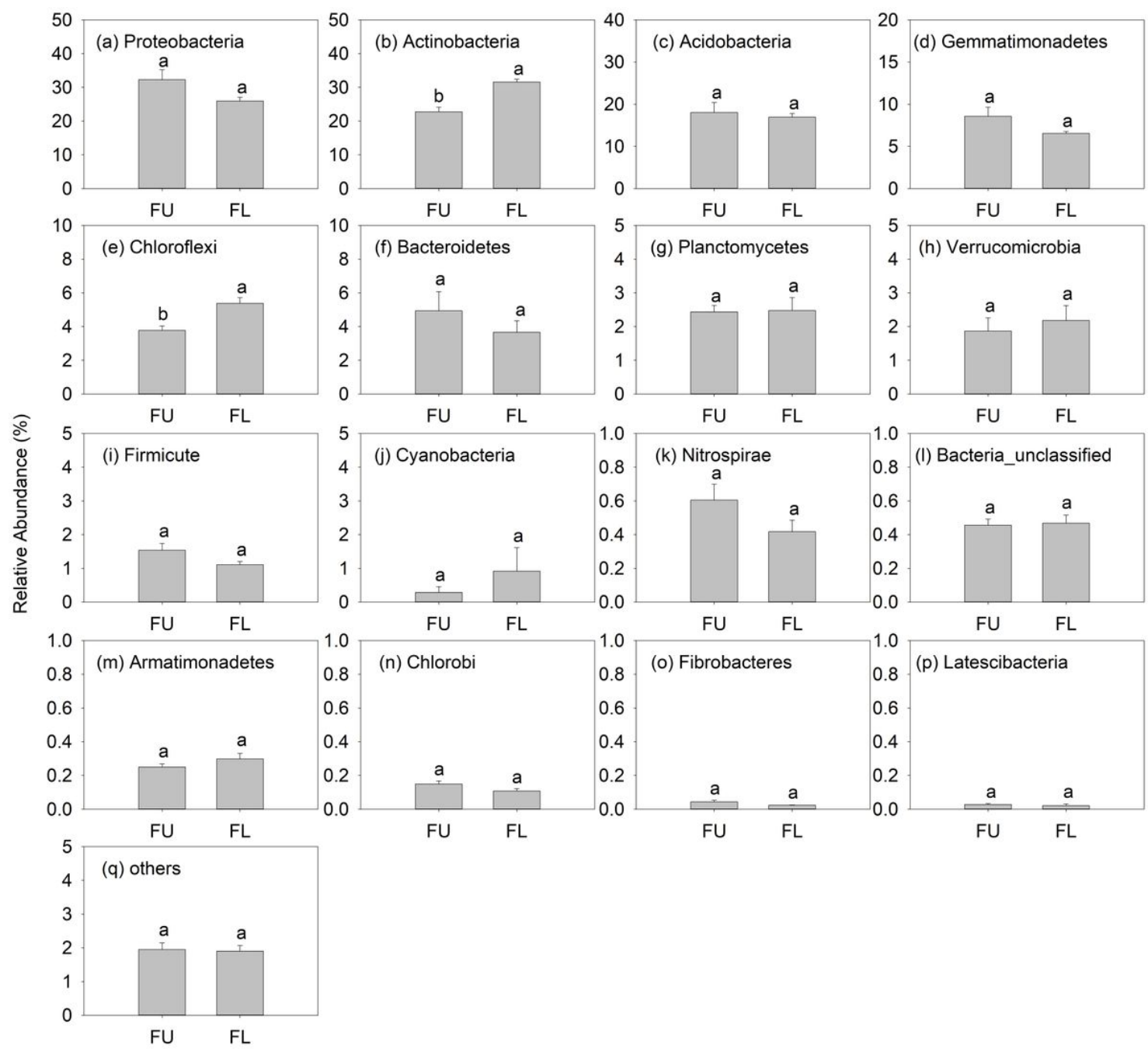

Figure 5

Relative abundance (\% of individual taxonomic group) of dominant bacteria phyla ( $m e a n \pm S E, n=4)$ in microbial communities following FU and FL of alfalfa. Different lowercase capital letters indicate statistically significant difference among communities at $\mathrm{P}=0.05$. 

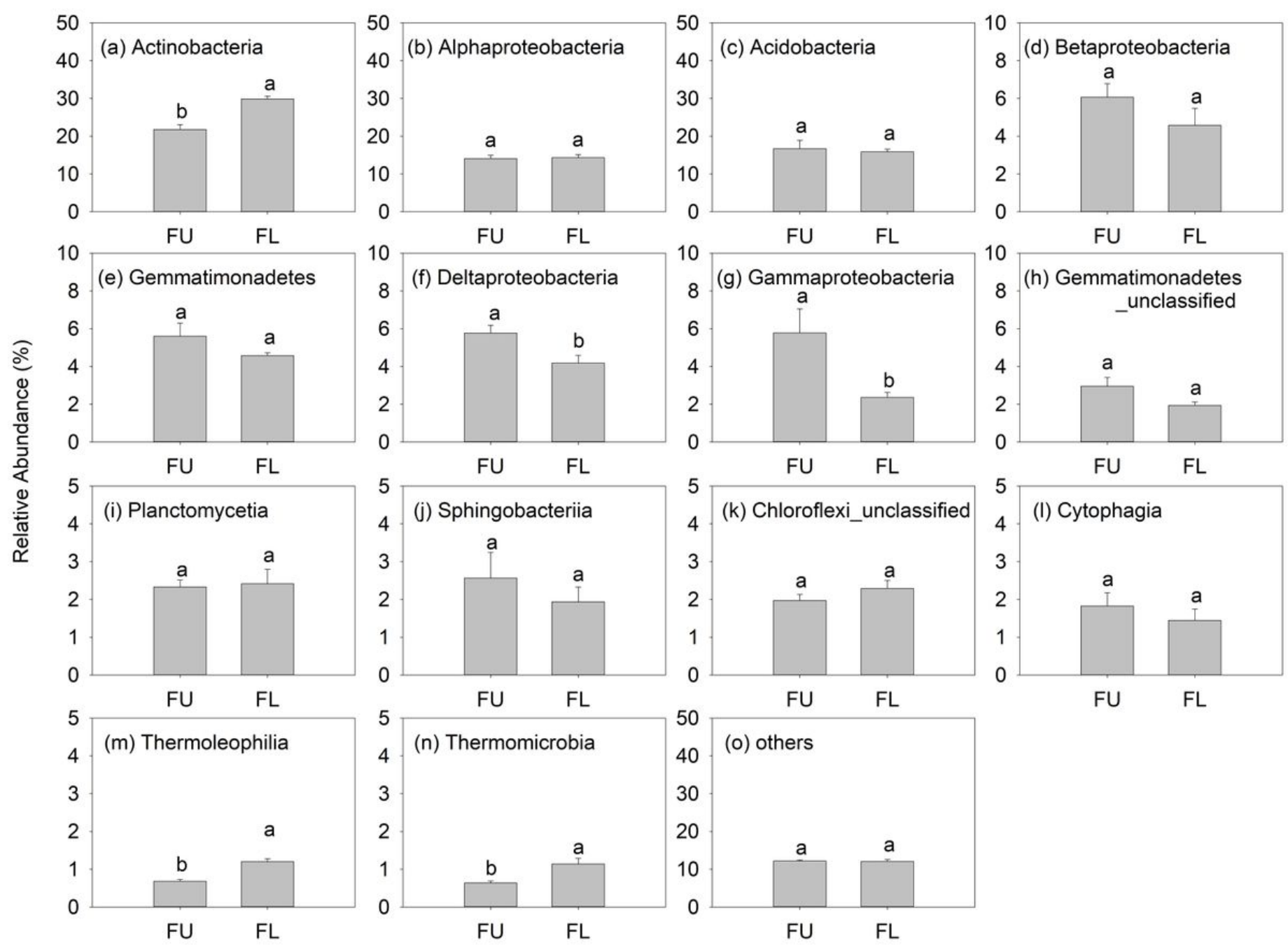

\section{Figure 6}

Relative abundance (\% of individual taxonomic group) of dominant bacteria classes (mean $\pm S E, n=4)$ in microbial communities following FU and FL. Different lowercase capital letters indicate statistically significant difference among communities at $\mathrm{P}=0.05$. 


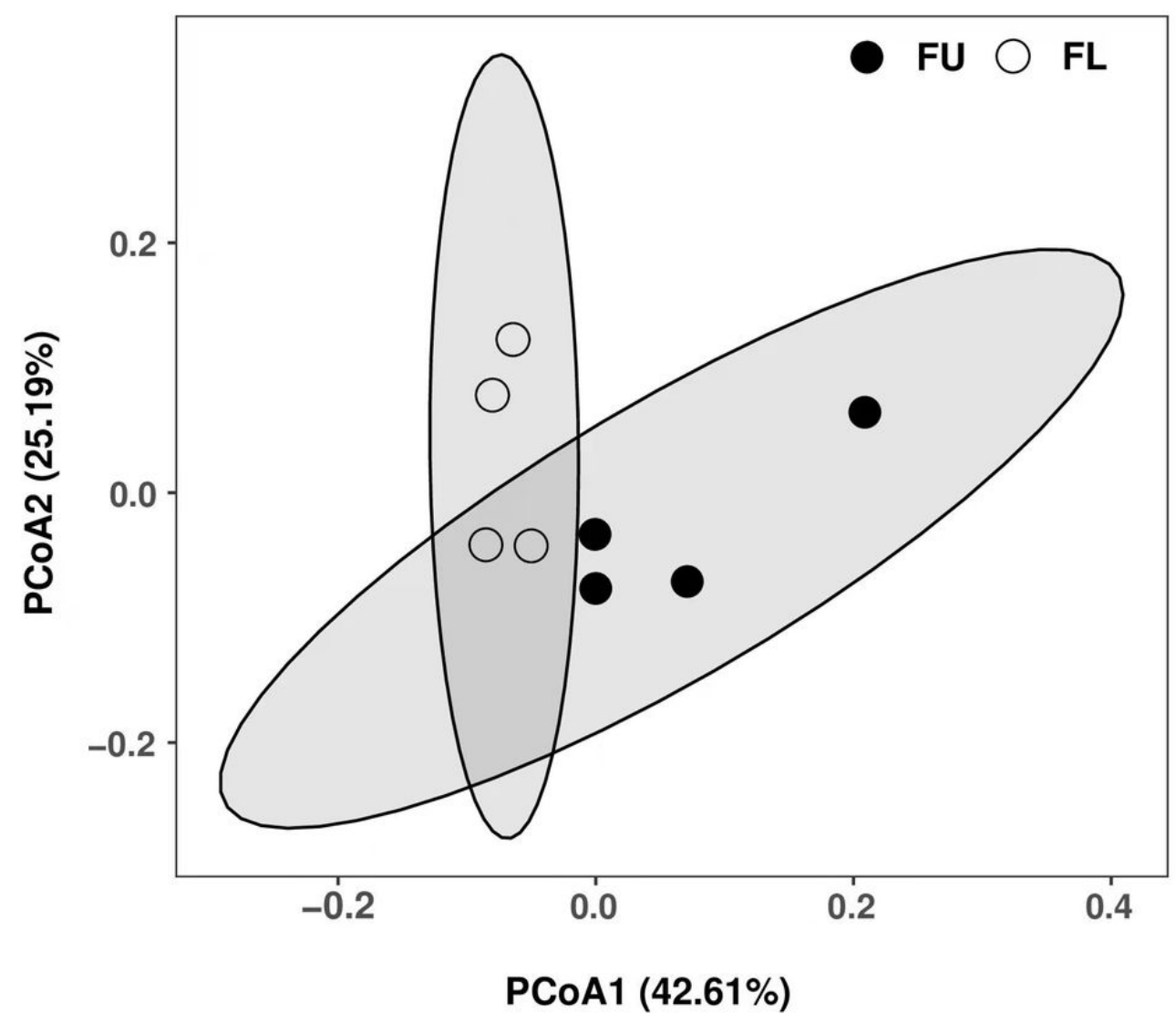

Figure 7

Principal co-ordinates analysis (PCOA) at operational taxonomic unit (OTU) level. FU= Furrow-bed seeding; FL=Flat-bed seeding. Solid circles show FU soil samples. Hollow circles show FL soil samples. 


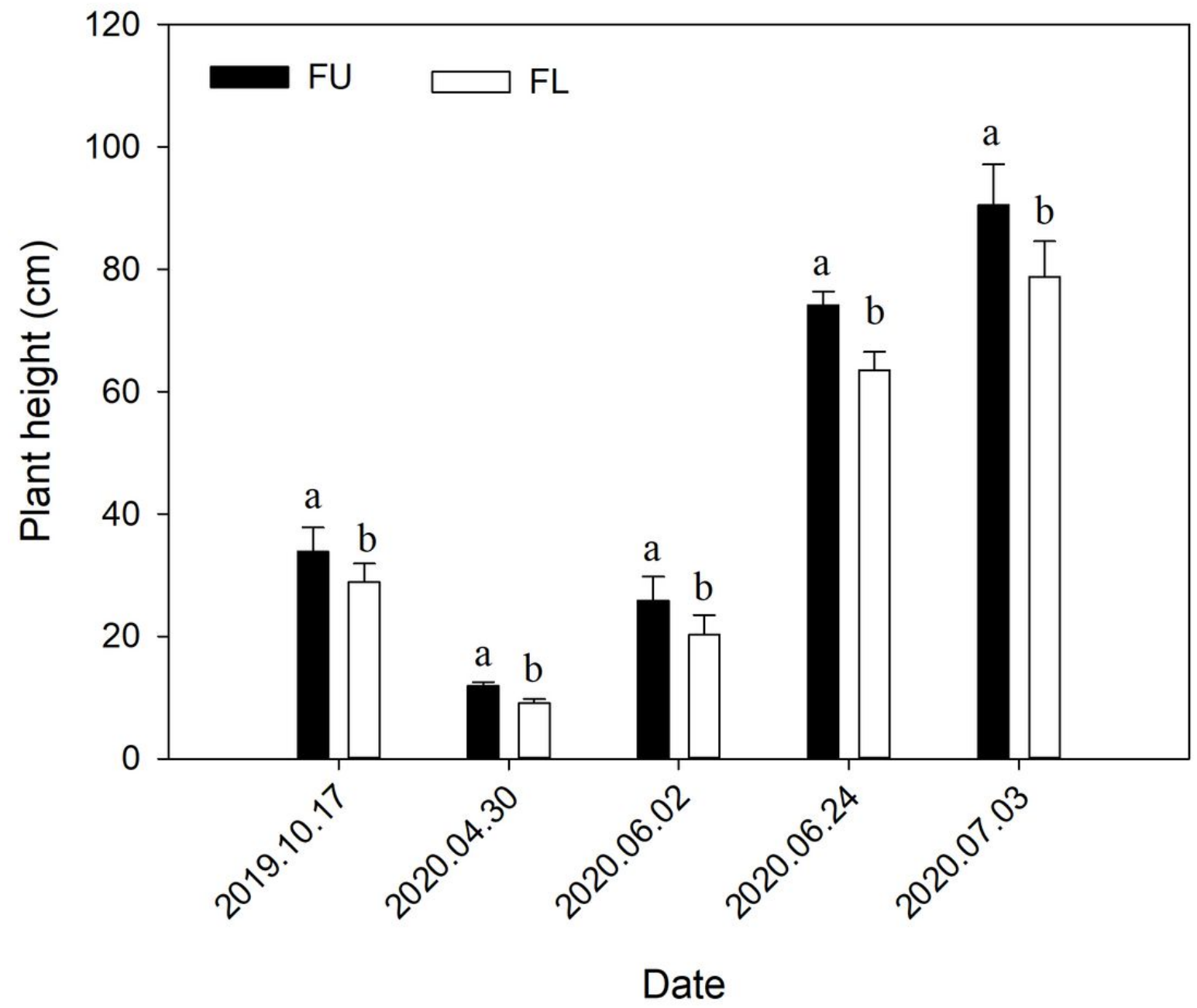

Figure 8

Effects of seeding pattern on alfalfa plant height in 2019 and 2020. FU= Furrow-bed seeding; FL=Flat-bed seeding. Values are means $(n=4) \pm S E$. Different lowercase letters indicate significant difference in plant height between FU and FL at each measurement time $(P \leq 0.05)$.

\section{Supplementary Files}

This is a list of supplementary files associated with this preprint. Click to download.

- Fig.S1.jpg 